\title{
Reverse development in Cnidaria
}

\author{
S. Piraino, D. De Vito, J. Schmich, J. Bouillon, and F. Boero
}

\begin{abstract}
Cnidarians have long been considered simple animals in spite of the variety of their complex life cycles and developmental patterns. Several cases of developmental conversion are known, leading to the formation of resting stages or to offspring proliferation. Besides their high regenerative and asexual-reproduction potential, a number of cnidarians can undergo ontogeny reversal, or reverse development: one or more stages in the life cycle can reactivate genetic programs specific to earlier stages, leading to back-transformation and morph rejuvenation. The switch is achieved by a variable combination of cellular processes, such as transdifferentiation, programmed cell death, and proliferation of interstitial cells. The potential for ontogeny reversal has limited ecological meaning and is probably just an extreme example of a more general strategy for withstanding unfavourable periods and allowing temporal persistence of species in the environment.
\end{abstract}

Résumé : Depuis longtemps, on considère les cnidaires comme des animaux simples, malgré la variété de leurs cycles biologiques et de leurs patterns de développement complexes. Il existe plusieurs cas de conversions au cours du développement qui mènent à la formation de stades de repos ou à la prolifération de rejetons. En plus de leur fort potentiel de régénération et de reproduction asexuée, plusieurs cnidaires peuvent subir un renversement de leur ontogenèse ou un développement inversé : un ou plusieurs stades dans le cycle biologique peuvent réactiver des programmes génétiques spécifiques de stades antérieurs, ce qui donne une rétro-transformation et un rajeunissement des morphes. Le revirement est provoqué par une combinaison variable de processus cellulaires, tels que la transdifférentiation, la mort cellulaire programmée et la prolifération de cellules interstitielles. Le potentiel de renversement ontogénique a une signification écologique limitée; il s'agit probablement d'un état extrême d'une stratégie plus générale pour survivre aux périodes défavorables et permettre à l'espèce de se maintenir dans le temps dans son milieu.

[Traduit par la Rédaction]

\section{The diversity of cnidarian ontogeny}

\section{The complexity of hydrozoan life cycles and the "immortal" jellyfish}

The life cycle of the Hydrozoa is typically characterized by the alternation of three life stages: the planula larva, the postlarval polyp stage (mainly colonial), and the adult stage, i.e., the medusa (Boero et al. 2002). The ciliated planula has been also interpreted as a motile gastrula, and the polyp as the true larval stage (Bouillon and Boero 2000). The planula lives only from a few hours to a few days before metamorphosis, whereas both polyp and medusa stages can have a much longer life-span (from days to years) (Bouillon 1994). This life cycle is usually invoked as being paradigmatic for the Medusozoa group (Hydrozoa, Scyphozoa, Cubozoa, and Staurozoa; see Marques and Collins 2004). However, sideways deviations from the norm are common (Fig. 1). Ancestral taxa (e.g., Actinulidae, Narcomedusae, and Trachymedusae) lack a polyp stage (Bouillon and Boero 2000); in contrast, members of derived families of the Hydroidomedusa group (e.g., Aglaopheniidae, Plumulariidae, and Sertulariidae) re-

Received 28 May 2004. Accepted 23 November 2004.

Published on the NRC Research Press Web site at http://cjz.nrc.ca on 2 February 2005.

S. Piraino, ${ }^{1}$ D. De Vito, J. Schmich, J. Bouillon, and F. Boero. Dipartimento di Scienze e Tecnologie Biologiche ed Ambientali, Università di Lecce, via per Monteroni, 73100 Lecce, Italy.

${ }^{1}$ Corresponding author (e-mail: stefano.piraino@unile.it). duced, in part or totally, the medusa stage by paedomorphosis (Boero and Bouillon 1987). In many cases, the polyp becomes the adult stage, and gametes can differentiate either in the hydranth body column, (e.g., in Hydra spp.) or within highly reduced medusae (fixed gonophores) retained by polymorphic polyp colonies. Other species can produce short-lived, free medusoid morphs characterized by reduced swimming and (or) feeding potential (e.g., Macrorynchia philippina (Kirchenpauer, 1872) (Gravier 1970) or Nemalecium lighti (Hargitt, 1924) (Gravier-Bonnet and Migotto 2000)). These morphs, called swimming gonophores by Boero and Bouillon (1989), are liberated with already mature gonads, and their dispersal from the polyp colony is usually limited (Boero et al. 2002).

In many hydrozoan species, the normal pace of the life cycle can be modified at some stages. Both planula and polyp stages can shrink and rest in low-metabolic-cost states (cysts, dormant hydrorhizae) to survive critical periods, being ready to reactivate cell proliferation and morphogenesis at the onset of favourable seasons (Boero et al. 1992). Polyp colonies can last for several years, annually producing large batches of sexually competent medusae, followed by periodic colony shrinkage and recurrent cycles of regenerative processes, without any obvious sign of senescence (Forrest 1963; Müller 1996). This process, also known as renovation, is a type of regeneration. In nature, renovation is a normal process in the hydroid colonies of many Leptomedusae, and may be repeated several times during their life-span, depending upon intrinsic factors (i.e., age of the colony, health of the colony, etc.) or sometimes upon the ecological condi- 
Fig. 1. Models of some hydrozoan life cycles. (A) Hydra spp. have no medusa stage and no planula larva. The gonads originate on the polyp body column; the new polyp hatches directly from a cuticled embryo. Asexual budding of new polyps is the most frequent mode of reproduction. (B) Hydractinia echinata (Fleming, 1828) has a highly reduced medusa stage that remains attached to the polyp in the form of fixed gonophores. Fertilization leads to the formation of a planula larva, which will undergo metamorphosis to develop into a polyp colony. (C) The life cycle of Hydractinia (Podocoryna) carnea includes a swimming medusa stage and a planula larva. Artificial detachment of late medusa buds leads to the development of medusae that are complete but reduced in size. In contrast, artificially detached early medusa buds are capable of transformation back into polyps. Such reverse transformation is not usually achieved by late medusa buds or liberated medusae. (D) Turritopsis nutricula has a typical three-stage life cycle: planula, polyp, and medusa. However, medusae at all stages of development retain the potential for life-cycle reversal; even spent medusae do not die, but transform back spontaneously into new polyp colonies.

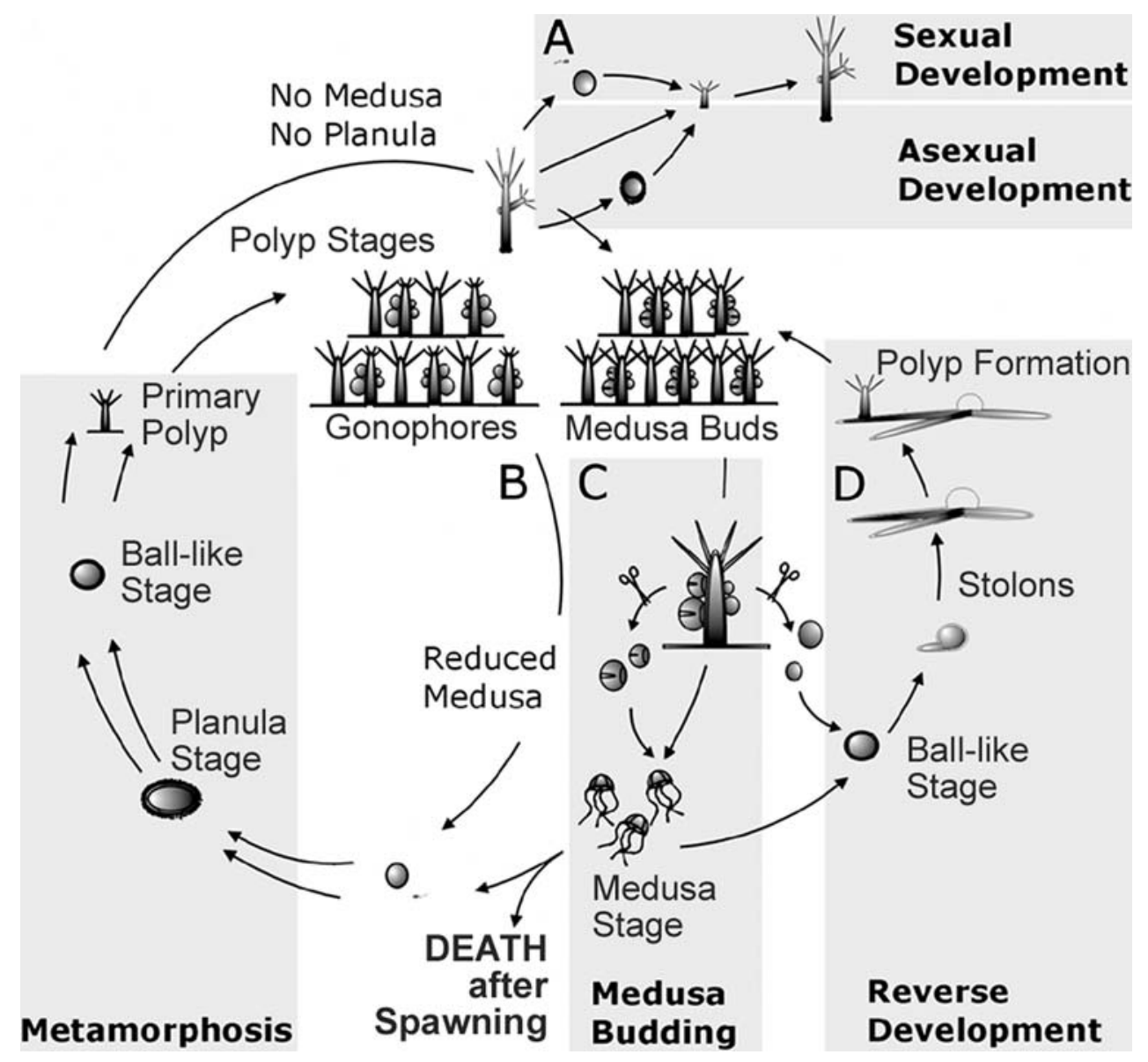

tions they face. Renovation is usually accomplished by changes in morphology and functional commitment of already specialized cells, a process known as transdifferentiation (Schmid 1992). Interstitial cells (I-cells) may partly contribute to the renovation process, but they are not a fundamental requisite. In fact, not all those species undergoing colony or polyp renovation have I-cells (Brien 1941). Moreover, cell replacement and differentiation along the body column, regeneration, and asexual reproduction are equally active processes in Hydra spp. populations experimentally deprived of I-cells (Brien and Reniers-Decoen 1955; Diehl and Bouillon 1966; Marcum and Campbell 1978). Renovation is rare, or perhaps less easy to observe, in Anthomedusae polyps, but it is known to occur (e.g., in Tubularia spp.; Tardent 1963). In marine Hydrozoa, regeneration and cell replacement occur by activation of epithelial smooth muscle cells, which then become stem cells by dedifferentiation (Schmid 1974).

At different levels, both polyp and medusa stages of

Hydroidomedusae can exhibit a combination of budding and regenerative processes (Boero et al. 2002). It is known that medusae of several species have the ability to bud (but not to metamorphose into) polyp structures before or even after initiation of processes of sex-cell determination (Boero et al. 2002). In addition, direct medusa budding from liberated medusae is known for several species. Large populations can be built up in time and space, allowing the species to cross, by following the currents, deep oceanic waters, where planulae may have few or no chances to settle. This type of medusa budding involves transdifferentiation of preexisting cell types on the manubrium, tentacular bulbs, radial canals, exumbrellar rim, marginal canal, subumbrellar rim, or even gonads (for further discussion and a species list see Boero et al. 2002 and references therein).

An additional potential has been discovered in a few species whose polyp stage can also be reformed from regressing tissues of sexual stages (Figs. 1C-1D). Müller (1913) first described such "reverse ontogeny" in Hydrozoa, having ob- 
served the formation of stolons and polyps from regressing medusa buds mechanically detached from the gonozooids of Hydractinia (Podocoryna) carnea (M. Sars, 1846). Only early medusa buds could undergo reverse development, whereas late buds developed into small but fully formed medusae (Frey 1968; Schmid 1972). Hauenschild (1956) observed the same potential in Eleutheria dichotoma Quatrefages, 1842 and Kakinuma (1969) reported a comparable process in Cladonema sp. and Cladonema uchidai Hirai, 1958, with the formation of hydrorhizal stolons from early medusa buds experimentally detached from the gonozooids. Also, Bavestrello et al. (2000) described a complex fragmentation process in polyp colonies of Hydractinia (Stylactaria) pruvoti (Motz-Kossovska, 1905) that is induced by strong water movements: fragmentation of gonozooids bearing medusa buds led to the early liberation of developing eumedusoids. As in $H$. carnea, mature eumedusoids of $H$. pruvoti started swimming and spawning, while early stages underwent a regressive transformation giving rise to stolons and polyps.

It is now known that the reverse transformation of $H$. carnea is due not only to regeneration by proliferation of I-cells, but also to the occurrence of cell-transdifferentiation processes (Schmid 1972; Schmid et al. 1982; Schmid and Alder 1984; Alder and Schmid 1987). Transdifferentiation is defined as a change in commitment and gene expression of well-differentiated, non-cycling somatic cells to other cell types directly or through their reversion to undifferentiated cells (Okada 1991). In Hydroidomedusae, transdifferentiation might be a common phenomenon in budding and regeneration, especially where no or few I-cells are located (Brien 1941). Manubrial budding of secondary medusae in a few species belonging to different families (Bougainvillidae, Hydractiniidae, Rathkeidae) originates only from differentiated ectodermal cells, with no aid from the I-cell compartment (Bouillon 1962; see also Boero et al. 2002 and references therein). All tissues of the newly formed medusae derive from transdifferentiating ectoderm. However, in all other cases, the contribution of transdifferentiation processes is still unstudied.

The fate of developing buds of Sarsia tubulosa (M. Sars, 1835) can be altered by sudden changes in temperature (Berrill 1953). Medusa buds can develop, depending on water temperature, either in normal free medusae or in sessile eumedusoids with rudimentary tentacles and lacking both mouth and ocelli. Moreover, when rearing of $S$. tubulosa is shifted to the temperature range $6-8^{\circ} \mathrm{C}$, medusa buds can be transformed back into polyp buds (Werner 1963). This process suggests the involvement of cell transdifferentiation and programmed cell death, as occurs in $H$. carnea.

In most cases, ontogeny reversal occurs in incompletely developed medusa buds with no sign of gonads. The potential for reverse ontogeny is suppressed in late bud stages with developing gonads, and in liberated medusae. The onset of sexual reproduction might thus be regarded as the point of no return in the ontogenetic sequence in any living organism, ultimately leading to aging and death (Stearns 1992). In cnidarians, as in most other organisms, germ-cell differentia- tion seems to represent a signal for irreversible somatic determination, preventing back-transformation of late medusa buds. However, studies on Turritopsis nutricula Mccrady, 1859 (Anthomedusae, Clavidae) (Fig. 2) demonstrated that this rule can be broken. Bavestrello et al. (1992) showed that newly liberated medusae of this species can revert to polyp stages; later, Piraino et al. (1996) showed that ontogeny reversal occurs at all stages of medusa growth, including the adult stage with mature gonads (Fig. $2 d$ ). Thus, rejuvenation of the medusa morph into the polyp stage is always possible in this species, and is not constrained by gamete differentiation. In $T$. nutricula, rejuvenation involves the contribution of both transdifferentiation and I-cell-proliferation processes (Piraino et al. 1996), together with the activation of celldeath programs (Carlà et al. 2003). These medusae react to unfavourable conditions (e.g., starvation, mechanical stress, temperature and salinity changes), starting reverse transformation into the polyp stage: a complete reduction of all medusa-specific organs and tissues, followed by differentiation of new, polyp-specific cell types and the formation of the polyp morph (Piraino et al. 1996). In T. nutricula, even senescence (started by the sexual maturation of the gonads) is a stress factor that consistently induces reverse transformation of medusae. This process would be hardly more remarkable if a butterfly were able to revert to its caterpillar stage. It must be considered a true metamorphosis, but in the opposite direction to larval metamorphosis. At the molecular level, it is reflected in a distinct pattern of stage-specific gene expressions (Spring et al. 2000; Yanze et al. 2001). Recently, young medusae of $T$. nutricula and even $H$. carnea were shown to undergo reverse transformation and rejuvenation to the polyp stage by exposure to cesium, a chemical inducer of metamorphosis (J. Schmich, unpublished data). In addition, reverse development has been recently demonstrated to occur also in Leptomedusae: young, immature medusae of Laodicea undulata (Forbes and Goodsir, 1851) are able to revert to the polyp stage (De Vito et al. ${ }^{2}$ ). Steps leading to back-transformation in L. undulata are comparable to those observed in young $T$. nutricula medusae (Piraino et al. 1996). The first signals of ontogeny reversal are thinning of the mesoglea and shortening of the tentacles. The medusa then becomes unable to swim and settles to the bottom of the culture vessel. The umbrella is reduced within a few hours, and the whole medusa is transformed into a cyst-like rounded mass of poorly differentiated cells. Periderm-covered hydrorhizae develop soon and the first "regenerated" polyp appears within 48-72 h of the initiation of the process. Within a month, new gonothecae are already reformed from the rejuvenated colony and, from there, secondary medusae are newly budded. Medusae of L. undulata with mature gonads were not observed and it is still not known if they retain the potential for ontogeny reversal also in sexually competent stages, as in T. nutricula.

The formation of stolons by back-transformation was also observed in mechanically detached medusoids of Cytaeis schneideri (Motz-Kossowska, 1905) (S. Piraino, unpublished observations) and from a newly liberated medusa of Clytia hemisphaerica (L., 1767) (De Vito et al. ${ }^{2}$ ). In both cases,

\footnotetext{
${ }^{2}$ D. De Vito, S. Piraino, J. Schmich, J. Bouillon, and F. Boero. Laodicea undulata (Forbes and Goodsir 1851) (Cnidaria, Hydrozoa), a leptomedusa with the potential for reverse ontogeny. Submitted for publication.
} 
Fig. 2. Reverse development of T. nutricula. (a) Free-living healthy medusa. (b) Transforming medusa, with the everted subumbrellar muscle layer (at left) and outer manubrium (at right). BrdU staining of DNA replicating nuclei. (c) Ball-like or cyst-like stage of a transforming medusa. BrdU staining of DNA replicating nuclei. (d) Butterfly-shaped remnant of an adult medusa of T. nutricula (settled on a glass slide) with four mature male gonads (white arrows), producing a hydrorhizal stolon characteristic of the polyp stage (black arrow). (e) A newly formed polyp from reverse development of a medusa (within $36-48 \mathrm{~h}$ at $24{ }^{\circ} \mathrm{C}$ ). Scale bars: $(a) 1 \mathrm{~mm}$; (b) $500 \mu \mathrm{m}$; (c) $300 \mu \mathrm{m}$; $(d$ and $e) 500 \mu \mathrm{m}$.

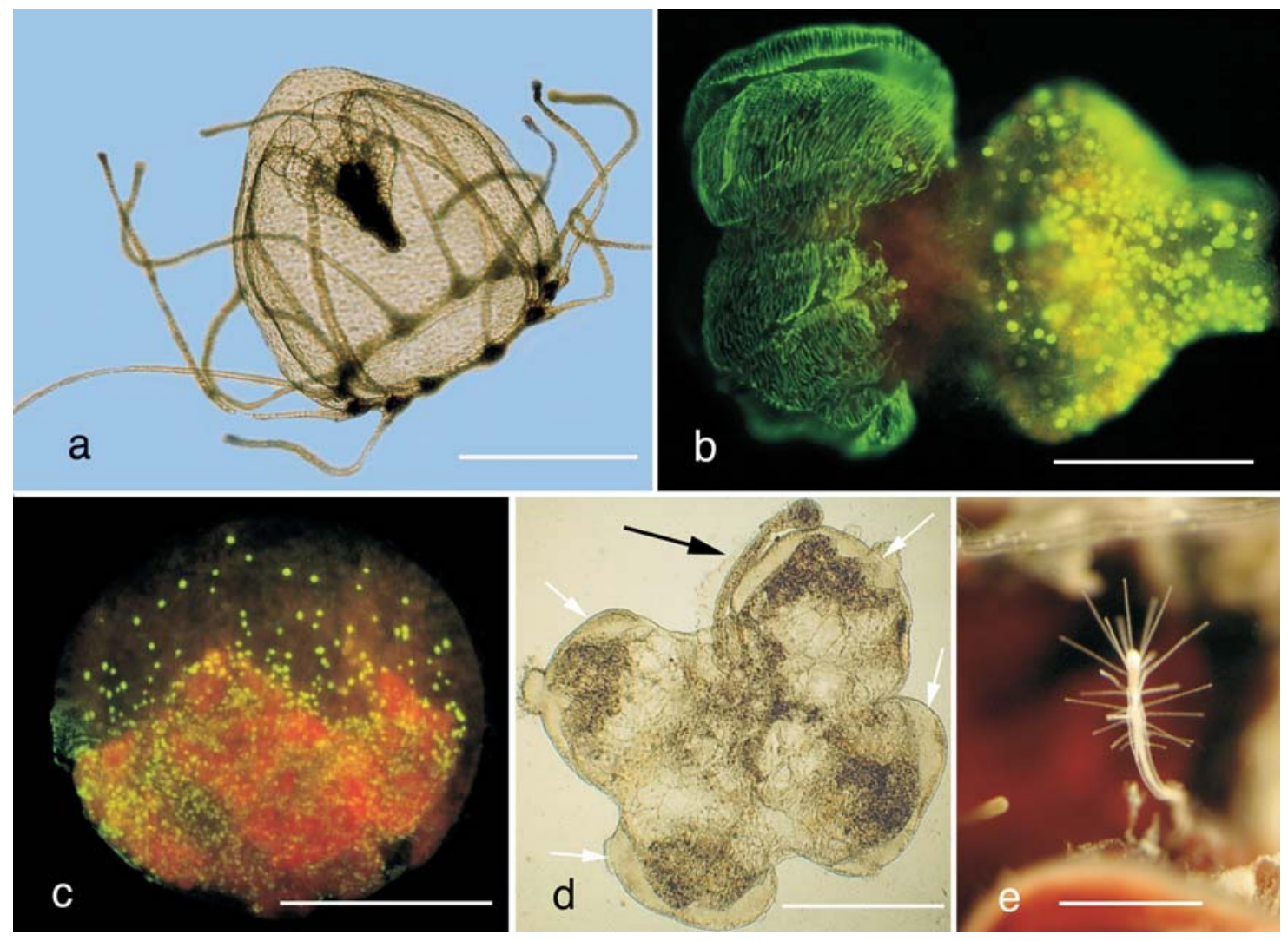

however, stolon formation was not followed - at least in our laboratory experiments — by polyp development.

\section{Back-transformation (Rückbildung) in Scyphozoa}

In Scyphozoa, the paradigm of the medusozoan life cycle (planula-polyp-medusa) is retained, but with the distinctive addition of a pre-adult stage, the ephyra, produced by transverse fission of the polyp (strobilation; see Spangenberg $1965,1968)$. The medusa phase predominates in the life cycle of most scyphozoans, and the polyp stage (scyphistoma) is in some cases significantly reduced or even completely suppressed (e.g., in the genera Atolla and Pelagia). Species of two coronate genera (Nausithoe, Thecoscyphus) lack a free medusa stage (Jarms 1997) but, unlike many Hydrozoa, Scyphozoa never completely lose a medusoid stage. Modifications of the basic scyphozoan cycle are the production of polyp resting stages, called podocysts (known in both Semeostomeae and Rhizostomeae; for a list of species see Arai 1997), and of "planula-cysts" (in the genus Cyanea; Brewer 1976 and references therein). Regeneration can be as powerful in the Scyphozoa as in the Hydrozoa. Scyphomedusae can regenerate lost organs and tissues, and new coronate polyp colonies can grow from individually excised polyps. A striking example of regeneration and asexual reproduction by means of "pseudoplanulae" was first discovered in Chrysaora sp. by Hérouard (1909), who described the autotomy of polyp tentacles leading to a ciliated "planula-like" stage, which was capable of locomotion and settlement to produce secondary polyps. Afterwards, LeshLaurie and Corriel (1973) demonstrated consistent regeneration of complete polyps from isolated tentacles of Aurelia aurita (L., 1758) scyphistomae. The process of propagule formation by autotomy of tentacles is also known in Hydrozoa (e.g., the limnomedusa Armorhydra janowiczi Swedmark and Teissier, 1958 (Campbell 1974); the hydroidomedusa H. pruvoti (Bavestrello et al. 2000)).

The first reports of true reverse development in Cnidaria were given by Hadzi (1909a, 1909b, 1912), who described back-transformation (Rückbildung) of ephyrae of Chrysaora hysoscella (L., 1766) to scyphistoma polyps under unfavourable environmental conditions. Reverse transformation of ephyrae into scyphopolyps was later observed also in Rhizostoma pulmo (Macri, 1778) (Paspaleff 1938) and A. aurita (Thiel 1963). Comparably, under unfavourable rearing conditions, the ephyrae of eight species of Coronatae may undergo ontogeny reversal, first regressing to planuloid masses of cells, and growing into polyps later (from weeks to months) (reviewed by Jarms 1997). The ability of Nausithoidae to produce planuloids is regarded as an ontogenetic strategy to minimize energy losses and enable survival and propagation in low-energy habitats, such as caves or deep seas (Jarms 1997). In this framework, Nausithoe planulo- 
phorus (Werner, 1971) shows the highest degree of specialization by retaining within the polyp peridermal tube all strobilae, which are eventually transformed into the planuloid stage, crowling out of the tube and settling a short distance from the parental polyp. As noted by Jarms (1997), this apogamic life cycle precludes the benefits of sexual recombination and should be considered an evolutionary deadend.

\section{Reversible metamorphosis in Anthozoa}

Anthozoa are considered the ancestral group of Cnidaria (Bridge et al. 1992; Collins 2002). Their simple life-cycle pattern consistently lacks a medusa stage, whereas dispersal is mainly delegated to planula larvae or occurs by fragmentation and drift of asexual propagules. Recently, Fautin (2002) reviewed the modes of cnidarian reproduction: two main modes of asexual reproduction, scissiparity (either transverse and longitudinal fission) and budding (sensu Bouillon 1994) are mainly found in Anthozoa (with the exception of Ceriantharia). Secondary modes of asexual reproduction are less common, like laceration of the pedal disk in some Actiniaria, or pinnitomy in some octocorals, whose tentacular pinnules can autotomize and fall from the parent colony to give rise to new polyps and, then, new colonies (Gohar 1940). Comparably, the tentacles of boloceroidid sea anemones can reconstitute new polyps (Cutress 1979; Pearse 2002). Tentacle or pinnule autotomy is a homologue of the above-mentioned formation of pseudoplanulae in Scyphozoa, with regeneration of complete polyps from autotomized or isolated tentacles of scyphistomes.

Polyp bail-out (Sammarco 1982) is an adaptive response to environmental stress, providing a way of escape and adult dispersal in a pocilloporid coral (also observed in Hydrozoa; see Gravier-Bonnet 1992). Polyps are able to leave their hard skeleton and detach from the parent colony. This process implies a partial rearrangement of the running genetic machinery, switching off the progressive assembly of inorganic skeletal components and partly reshaping the polyp column. A further step towards reactivation of early developmental programs in Anthozoa is found again within the family Pocilloporidae. Richmond (1985) described "reversible metamorphosis" in Pocillopora damicornis (L., 1758), whose primary polyps may, under unfavourable conditions, abandon the primary corallites shortly after metamorphosis and regress to a planula-like stage. Such secondary larvae could search for appropriate sites of settlement and metamorphose again. However, nothing is known about such reverse transformation at the cellular level, including the potential contribution from the I-cell compartment or from transdifferentiation processes.

\section{Discussion}

Many metazoans, namely Porifera, Cnidaria, Platyhelminthes, Placozoa, Nemertea, Rotifera, Nematoda, Acanthocephala, Arthropoda, Tardigrada, Ectoprocta, and Tunicata, are able to withstand unfavourable conditions by producing resting stages through different processes (e.g., encystment, degrowth or reduction in size, survival budding; see Piraino et al. 1996 and references therein). These can be envisaged as developmental conversions along the normal ontogenetic path. Reverse development, however, seems to be a distinctive feature of cnidarians. A growing mass of information suggests that the potential for ontogeny reversal is more widespread in Cnidaria than was previously thought.

In most cases, the transformation of body portions into earlier structures represents a way to produce either resting or dispersive stages without sexual reproduction. This possibility exists in both polyps (which give rise to planula-like structures) and young medusae (which give rise to polyps). In the case of $T$. nutricula, and a small group of other species, however, a completely different interpretation is called for. The medusae of $T$. nutricula, in fact, invariably transform into polyps under laboratory conditions (Piraino et al. 1996) and have been called immortal by the nonscientific press. From each medusa undergoing reverse ontogeny, a new colony can potentially originate, which in turn will produce new copies of the original medusa, leading to an exponential increase in the total number of clonemate offspring. To date, this potential has been repeatedly demonstrated in the laboratory with a large number of observations in T. nutricula (Piraino et al. 1996). By implication, they could attain immortality. But if this potential for avoiding death were expressed in the field, these animals would saturate the world's oceans! Instead, we see that they suffer mortality, and population growth is kept under control. It is probable that such a great potential for ontogeny reversal has limited meaning and is just an extreme example of a more general strategy for withstanding unfavourable periods and allowing temporal persistence of species in the environment.

As already mentioned, the potential for reverse development could be present, but hidden, in other cnidarians. In laboratory experiments the lack of unknown field factors (e.g., species-specific relationships with marine bacteria) may obscure possible back-transformation, but the genetic machinery may remain functional, as is also demonstrated by the artificial activation of reverse development in adult medusae of $H$. carnea by chemical inducers of metamorphosis.

To date, it seems that only scyphozoan ephyrae, but not adult medusae, can revert to the polyp stage and, within Anthozoa, only coral primary polyps can revert to planula larvae. However, available information on Staurozoa and Cubozoa is scant and the life cycles of many cnidarians still need to be elucidated. Therefore, we can reasonably assume that new cases of reverse development could be discovered. Other species can retain the potential for transformation, but (i) it can be transiently expressed only under extraordinary conditions, or (ii) the genetic program involved in the transformation process can be activated, but only few species retain the whole signalling cascades needed for the completion of morph reversal.

As often happens in experimental biology, extreme cases can become a paradigm for uncovering general, albeit less extreme, patterns. Boero et al. (1997) theorized that the genome of hydromedusan species with complex life cycles might be (functionally) divided into two main portions, one coding for the polyp and one coding for the medusa stage. The two main stages of the life cycle, in fact, possess different cell types and organs. As was noted by Boero et al. (1998), hydrozoan polyps are diploblastic, whereas their medusae are triploblastic and possibly coelomate, since their subumbrellar cavity originates by cavitation (i.e., schizo- 
coely) within a third cell layer that, in turn, differentiates into the striated muscle lining the subumbrella (striated muscle is mesodermic in all other Metazoa). With ontogeny reversal by transdifferentiation, medusa cells transform into polyp cells, with a total reprogramming of their fate. The one-way route of developmental programs, always leading to death, is inverted! In T. nutricula, ontogeny reversal is caused by both environmental cues (sublethal stress) and senescence, activating a trigger that can switch on or restart the "reading" of the genetic information almost from the very beginning. As is often the case, epigenetic and genetic cues concur in defining developmental patterns. The discovery of such switching mechanisms is a further step towards clarifying the mechanisms of senescence and rejuvenation, and might represent a breakthrough in developmental biology in general (Boero 1998).

\section{Acknowledgments}

Many thanks are extended to Prof. Volker Schmid (Basel), who guided us to an understanding of reverse development and transdifferentiation in Hydrozoa and provided valuable comments on the manuscript. Financial support was provided by Ministero dell'Istruzione, dell'Università e della Ricerca $(60 \%$, Cofinanziamento progetti di ricerca di interesse nazionale projects and Fondo per gli investimenti dell ricerca di base), the Administration of the Province of Lecce, Istituto centrale per la ricerca scientifica e tecnologica applicata al mare ("Identificazione e distribuzione delle specie non indigene nel Mediterraneo" project), the European Union (Marie Curie contract HPMD-CT-2001-00099, and the Marine Biodiversity and Ecosystem Functioning Network of Excellence), the National Science Foundation of the USA (Partnerships for Enhancing Expertise in Taxonomy: NSF DEB-9978131 project on the Hydrozoa).

\section{References}

Alder, H., and Schmid, V. 1987. Cell cycles and in vitro transdifferentiation and regeneration of isolated, striated muscle of jellyfish. Dev. Biol. 124: 358-369.

Arai, M.N. 1997. A functional biology of Scyphozoa. Chapman and Hall, London.

Bavestrello, G., Sommer, C., and Sarà, M. 1992. Bi-directional conversion in Turritopsis nutricula (Hydrozoa). In Aspects of hydrozoan biology. Edited by J. Bouillon, F. Boero, F. Cicogna, J.M. Gili, and R.G. Hughes. Sci. Mar. 56: 137-140.

Bavestrello, G., Puce, S., Cerrano, C., Castellano, L., and Arillo A. 2000. Water movement activating fragmentation: a new dispersal strategy for hydractiniid hydroids. J. Mar. Biol. Assoc. U.K. 80: 361-362.

Berrill, N.J. 1953. Growth and form in gymnoblastic hydroids. VII. Growth and reproduction in Syncoryne and Coryne. J. Morphol. 92: 273-302.

Boero, F. 1998. Ontogeny. In 1999 McGraw-Hill yearbook of science and technology. McGraw-Hill, New York. pp. 265-258.

Boero, F., and Bouillon, J. 1987. Inconsistent evolution and paedomorphosis among the hydroids and medusae of the Athecatae/ Anthomedusae and the Thecatae/Leptomedusae (Cnidaria, Hydrozoa). In Modern trends in the systematics, ecology and evolution of hydroids and Hydromedusae. Edited by J. Bouillon, F. Boero,
F. Cicogna, and P.F.S. Cornelius. Clarendon Press, Oxford. pp. 229-250.

Boero, F., and Bouillon, J. 1989. An evolutionary interpretation of anomalous medusoid stages in the life cycle of some Leptomedusae (Cnidaria). In Reproduction, genetics and distributions of marine organisms. Edited by J.S.Ryland and P.A. Tyler. Olsen and Olsen, Fredensborg, Denmark. pp. 37-41.

Boero, F., Bouillon, J., and Piraino, S. 1992. On the origins and evolution of hydromedusan life cycles (Cnidaria, Hydrozoa). In Sex origin and evolution. Edited by R. Dallai. Sel. Symp. Monogr. U.Z.I. 6: 59-68.

Boero, F., Bouillon, J., Piraino, S., and Schmid, V. 1997. Diversity of hydromedusan life cycles: ecological implications and evolutionary patterns. In Proceedings of the 6th International Conference on Coelenterate Biology, Noordwijkerhout, the Netherlands, 16-21 July 1995. Edited by J.C. den Hartog, L.P. van Ofwegen, and S. van der Spoel. Nationaal Natuurhistorisch Museum, Leiden, the Netherlands. pp. 53-62.

Boero, F., Gravili, C., Pagliara, P., Piraino, S., Bouillon, J., and Schmid, V. 1998. The cnidarian premises of metazoan evolution: from triploblasty, to coelom formation, to metamery. Ital. J. Zool. 65: 5-9.

Boero, F., Bouillon, J., Piraino, S., and Schmid, V. 2002. Asexual reproduction in the Hydrozoa (Cnidaria). In Reproductive biology of invertebrates. Vol. XI. Progress in asexual reproduction. Edited by R.N. Hughes. Oxford \& IBH Publishing Co. Pvt. Ltd., New Delhi. pp. 141-158.

Bouillon, J. 1962. Sur le bougeonnement médusaire manubrial de Rathkea octopunctata. Ann. Soc. R. Zool. Belg. 92: 7-25.

Bouillon, J. 1994. Embranchement des Cnidaires (Cnidaria). In Traité de Zoologie. Vol. 3(2). Edited by P.P. Grassé and D. Doumenc. Masson, Paris. pp. 1-28.

Bouillon, J., and Boero, F. 2000. Phylogeny and classification of Hydroidomedusae. The Hydrozoa: a new classification in the light of old knowledge. Thalassia Salentina, 24: 1-46.

Brewer, R.H. 1976. Larval settling behavior in Cyanea capillata. Biol. Bull. (Woods Hole), 150: 183-199.

Bridge, D., Cunningham, C.W., Schierwater, B., DeSalle, R., and Buss, L. 1992. Class-level relationships in the phylum Cnidaria: evidence from mitochondrial genome structure. Proc. Natl. Acad. Sci. U.S.A. 89: 8750-8763.

Brien, P. 1941. Remarques au sujet des conceptions relatives à l'existence et à la pérennité, chez les hydroïdes, d'une réserve embryonaire et d'une lignée germinale, à propos du bourgeonnement et des potentialités de l'ectoderme de Cladonema radiatum (Duj.). Ann. Soc. R. Zool. Belg. 72: 37-62.

Brien, P., and Reniers-Decoen, M. 1955. La signification des cellules interstitielles des Hydres d'eau douce et le problème de la réverse embryonnaire. Bull. Biol. Fr. Belg. 89: 258-325.

Campbell, R. 1974. Cnidaria. In Reproduction of marine invertebrates. Vol. I. Acoelomate and pseudocoelomate metazoans. Chap. 3. Edited by A.C. Giese and J.S. Pearse. Academic Press, New York. pp. 133-199.

Carlà, E.C., Pagliara, P., Piraino, S., Boero, F., and Dini, L. 2003. Morphological and ultrastructural analysis of Turritopsis nutricula during life cycle reversal. Tissue Cell, 35: 213-222.

Collins, A.G. 2002. Phylogeny of Medusozoa and the evolution of cnidarian life cycles. J. Evol. Biol. 15: 418-432.

Cutress, C.E. 1979. Bunodeopsis medusoides Fowler and Actinodiscus neglectus Fowler, two Tahitian sea anemones: redescription and biological notes. Bull. Mar. Sci. 29: 96-109.

Diehl, F.A., and Bouillon, J. 1966. Observations sur les potentialités morphogénétiques des tissus irradiés de Cordylophora caspia (Pallas). Bull. Cl. Sci. Acad. R. Belg. 52: 138-146. 
Fautin, D.G. 2002. Reproduction in Cnidaria. Can. J. Zool. 80: 1735-1754.

Forrest, H. 1963. Immortality and Pearl's survivorship curve for Hydra. Ecology, 44: 609-610.

Frey, J. 1968. Die Entwicklungsleistungen der Medusenknospen und Medusen von Podocoryne carnea M. Sars nach Isolation und Dissoziation. Wilhelm Roux' Arch. Entwicklungsmech. Org. 160: 428-464.

Gohar, H.A.F. 1940. Studies on the Xeniidae of the Red Sea: their ecology, physiology, taxonomy and phylogeny. Publ. Mar. Biol. Stn. Al Ghardaqa, 3: 27-78.

Gravier, N. 1970. Libération des médusoides par Macrorhynchia philippina Kirchenpauer, 1872 (Hydrozoa, Plumulariidae). Recl. Trav. Stn. Mar. Endoume Fac. Sci. Mars. 10: 253-257.

Gravier-Bonnet, N. 1992. Cloning and dispersal by buoyant autotomised hydranths of a thecate hydroid (Cnidaria; Hydrozoa). Sci. Mar. 56: 229-236.

Gravier-Bonnet, N., and Migotto, A.E. 2000. Gonangium development and medusoid of Nemalecium lighti (Hargitt, 1924) (Cnidaria: Hydrozoa, Haleciidae). Sci. Mar. 64: 207-213.

Hadzi, J. 1909a. Einige Kapitel aus der Entwicklungsgeschichte von Chrysaora. Arb. Zool. Inst. Univ. Wien, 17: 17-44.

Hadzi, J. 1909b. Rückgängig gemachte Entwicklung einer Scyphomeduse. Zool. Anz. 34.

Hadzi, J. 1912. Die Reduktion des Scyphopolypen und der Ephyra von Chrysaora. In Proceedings of the VIII International Zoological Congress, Graz, Austria, 1910. G. Fisher Verlag, Jena. pp. 578-594.

Hauenschild, C. 1956. Experimentelle Untersuchungen über die Entstehung asexueller Klone bei der Hydromeduse Eleutheria dichotoma. Z. Naturforsch. 11: 394-402.

Hérouard, E. 1909. Sur les cycles évolutifs d'un Scyphistome. C. R. Hebd. Seanc. Acad. Sci. (Paris), 148: 320-323.

Jarms, G. 1997. The polyps of Coronatae (Scyphozoa):a review and some new results. In Coelenterate Biology: Proceedings of the 6th International Congress of Coelenterate Biology, Nordwijkerhout, the Netherlands, 16-21 July 1995. Edited by J.C. den Hartog, L.P. van Ofwegen, and S. van der Spoel. Nationaal Natuurhistorisch Museum, Leiden, the Netherlands. pp. 271-278.

Kakinuma, Y. 1969. On the differentiation of the isolated medusa bud of the hydrozoans, Cladonema uchidai and Cladonema sp. Bull. Mar. Biol. Stn. Asamushi, 13: 169-172.

Lesh-Laurie, G.E., and Corriel, R. 1973. Scyphistoma regeneration from isolated tentacles in Aurelia aurita. J. Mar. Biol. Assoc. U.K. 53: 885-894.

Marcum, B.A., and Campbell, R.D. 1978. Development of Hydra lacking nerve and interstitial cells. J. Cell Sci. 29: 17-33.

Marques, A.C., and Collins, A.G. 2004. Cladistic analysis of Medusozoa and cnidarian evolution. Invertebr. Biol. 123: 23-42.

Müller, H.C. 1913. Die Regeneration der Gonophore bei den Hydroiden und anschliessende biologische Beobachtungen I. Athecata. Arch. Entwicklungsmech. Org. 37: 319-419.

Müller, W.A. 1996. Pattern formation in the immortal Hydra. Trends Genet. 12: 91-96.
Okada, T.S. 1991. Transdifferentiation. Clarendon Press, Oxford.

Paspaleff, G.V. 1938. Ueber die Entwicklung von Rhizostoma pulmo Agassiz Arb. Biol. Meeres Stn. Varna, 7: 1-17.

Pearse, V.B. 2002. Prodigies of propagation: the many modes of clonal replication in boloceroidid sea anemones (Cnidaria, Anthozoa, Actiniaria). Invertebr. Reprod. Dev. 41: 201-213.

Piraino, S., Boero, F., Aeschbach, B., and Schmid, V. 1996. Reversing the life cycle: medusae trasforming into polyps and cell transdifferentiation in Turritopsis nutricula (Cnidaria, Hydrozoa). Biol. Bull. (Woods Hole), 190: 302-312.

Richmond, R.H. 1985. Reversible metamorphosis in coral planula larvae. Mar. Ecol. Prog. Ser. 22: 181-185.

Sammarco, P.W. 1982. Polyp bail-out: an escape response to environmental stress and a new means of reproduction in corals. Mar. Ecol. Prog. Ser. 10: 57-65.

Schmid, V. 1972. Untersuchungen über Dedifferenzierungsvorgänge bei Medusenknospen und Medusen von Podocoryne carnea M. Sars. Wilhelm Roux' Arch. Entwicklungsmech. Org. 169: 281307.

Schmid, V. 1974. Regeneration in medusa buds and medusae of Hydrozoa. Am. Zool. 4: 773-781.

Schmid, V. 1992. Transdifferentiation in medusae. Int. Rev. Cytol. 142: 213-261.

Schmid, V., and Alder, H. 1984. Isolated, mononucleated, striated muscle can undergo pluripotent transdifferentiation and form a complex regenerate. Cell, 38: 801-810.

Schmid, V., Wydler M., and Alder, H. 1982. Transdifferentiation and regeneration in vitro. Dev. Biol. 92: 476-488.

Spangenberg, D.B. 1965. A study of strobilation in Aurelia aurita under controlled conditions. J. Exp. Zool. 160: 1-10.

Spangenberg, D.B. 1968. Recent studies of strobilation in jellyfish. Oceanogr. Mar. Biol. Ann. Rev. 6: 231-247.

Spring, J., Yanze, N., Middel, A.M., Stierwald, M., Gröger, H., and Schmid, V. 2000. The mesoderm specification factor twist in the life cycle of jellyfish. Dev. Biol. 228: 363-375.

Stearns, S.C. 1992. The evolution of life histories. Oxford University Press, New York.

Tardent, P. 1963. Regeneration in the Hydrozoa. Biol. Rev. Camb. Philos. Soc. 38: 293-333.

Thiel, H. 1963. Untersuchungen über die Entstehung abnormer Scyphistomae, Strobilae und Ephyrae von Aurelia aurita Lam. und ihre theoretische Bedeutung. Zool. Jahrb. Abt. Anat. Ontog. Tiere, 81: 311-358.

Werner, B. 1963. Effect of some environmental factors on differentiation and determination in marine Hydrozoa, with a note on their evolutionary significance. Ann. N.Y. Acad. Sci. 105: 461488.

Werner, B. 1971. Stephanoscyphus planulophorus n.spec., ein neuer Scyphopolyp mit einem neuen Entwicklungsmodus. Helgol. Wiss. Meeresunters. 22: 120-140.

Yanze, N., Spring, J., Schmidli, C., and Schmid, V. 2001. Conservation of Hox/ParaHox-related genes in the early development of a cnidarian. Dev. Biol. 236: 89-98. 